Article

\title{
Biglycan- and Sphingosine Kinase-1 Signaling Crosstalk Regulates the Synthesis of Macrophage Chemoattractants
}

\author{
Louise Tzung-Harn Hsieh ${ }^{1}$, Madalina-Viviana Nastase ${ }^{1,5}$, Heiko Roedig ${ }^{1}$, \\ Jinyang Zeng-Brouwers ${ }^{1}$, Chiara Poluzzi ${ }^{1}$, Stephanie Schwalm ${ }^{1}$, Christian Fork ${ }^{2}$, \\ Claudia Tredup ${ }^{1}$, Ralf P. Brandes ${ }^{2}$, Malgorzata Wygrecka ${ }^{3}$, Andrea Huwiler ${ }^{4}$, \\ Josef Pfeilschifter ${ }^{1}$ and Liliana Schaefer ${ }^{1, *}$
}

1 Pharmazentrum Frankfurt, Institut für Allgemeine Pharmakologie und Toxikologie, Klinikum der Goethe Universität, Theodor-Stern-Kai 7, Frankfurt am Main 60590, Germany; hsiehlouise@gmail.com (L.T.-H.H.); madalina.nastase@gmail.com (M.-V.N.); heiko.roedig@live.de (H.R.); jinyangzeng@web.de (J.Z.-B.); chiarapoluzzi@yahoo.it (C.P.); s.schwalm@med.uni-frankfurt.de (S.S.); tredup@em.uni-frankfurt.de (C.T.); pfeilschifter@em.uni-frankfurt.de (J.P.)

2 Institut für Kardiovaskulare Physiologie, Klinikum der Goethe-Universität, Theodor-Stern-Kai 7, Frankfurt am Main 60590, Germany; fork@vrc.uni-frankfurt.de (C.F.); brandes@vrc.uni-frankfurt.de (R.P.B.)

3 Department of Biochemistry, Faculty of Medicine, Universities of Giessen and Marburg Lung Center, Friedrichstrasse 24, Giessen 35392, Germany; malgorzata.wygrecka@innere.med.uni-giessen.de

4 Institute of Pharmacology, University of Bern, Inselspital INO-F, Bern CH-3010, Switzerland; huwiler@pki.unibe.ch

5 National Institute for Chemical-Pharmaceutical Research and Development, 112 Vitan Avenue, Bucharest 031299, Romania; madalina.nastase@gmail.com

* Correspondence: schaefer@med.uni-frankfurt.de; Tel.: +49-696-301-7899

Academic Editor: Cheorl-Ho Kim

Received: 14 February 2017; Accepted: 6 March 2017; Published: 9 March 2017

\begin{abstract}
In its soluble form, the extracellular matrix proteoglycan biglycan triggers the synthesis of the macrophage chemoattractants, chemokine (C-C motif) ligand CCL2 and CCL5 through selective utilization of Toll-like receptors (TLRs) and their adaptor molecules. However, the respective downstream signaling events resulting in biglycan-induced CCL2 and CCL5 production have not yet been defined. Here, we show that biglycan stimulates the production and activation of sphingosine kinase 1 (SphK1) in a TLR4- and Toll/interleukin (IL)-1R domain-containing adaptor inducing interferon (IFN)- $\beta$ (TRIF)-dependent manner in murine primary macrophages. We provide genetic and pharmacological proof that SphK1 is a crucial downstream mediator of biglycan-triggered CCL2 and CCL5 mRNA and protein expression. This is selectively driven by biglycan/SphK1-dependent phosphorylation of the nuclear factor NF- $\mathrm{KB}$ p65 subunit, extracellular signal-regulated kinase (Erk)1/2 and p38 mitogen-activated protein kinases. Importantly, in vivo overexpression of soluble biglycan causes Sphk1-dependent enhancement of renal CCL2 and CCL5 and macrophage recruitment into the kidney. Our findings describe the crosstalk between biglycanand SphK1-driven extracellular matrix- and lipid-signaling. Thus, SphK1 may represent a new target for therapeutic intervention in biglycan-evoked inflammatory conditions.
\end{abstract}

Keywords: damage-associated molecular pattern; small leucine-rich proteoglycan; toll-like receptors; chemoattractant; extracellular matrix; lipid signaling; sphingolipid; macrophage 


\section{Introduction}

Inflammation can be triggered by various external microbial stimuli as well as by endogenous molecules under sterile conditions. The latter are called damage-associated molecular patterns (DAMPs) and are released following cell death or tissue injury [1].

Biglycan, a small leucine-rich proteoglycan (SLRP) of the extracellular matrix (ECM) [2] is normally sequestered in the ECM and therefore inactive as inflammatory trigger [3,4]. However, following tissue stress, biglycan is proteolytically released from the ECM and in its soluble form acts as a DAMP, thereby initiating a sterile inflammatory response [5]. Besides its liberation from the ECM, biglycan can also be synthesized de novo by macrophages and resident cells in inflamed tissues [5-7]. Soluble biglycan is a high-affinity ligand of the Toll-like receptors (TLR)2 and TLR4, mimicking the response to gram-positive (via TLR2) and gram-negative (via TLR4) pathogens $[5,6]$. By binding to TLR2/4 with downstream activation of the extracellular signal-regulated kinase (Erk)1/2 and p38 mitogen-activated protein kinases (MAPKs) as well as the nuclear factor $\mathrm{k}$-light-chain-enhancer of activated B-cells (NF- $\mathrm{KB}$ ) pathway, biglycan triggers the synthesis of tumor necrosis factor (TNF) $\alpha$ and interleukin-1 (IL-1) $\beta$ cytokines $[5,8,9]$.

There are two adapter molecules essential for the TLR signaling: the myeloid differentiation primary response protein (MyD88) and Toll/IL-1R domain-containing adaptor inducing interferon (IFN)- $\beta$ (TRIF). While signaling through TLR4 involves both MyD88 and TRIF adapters the TLR2 signaling pathway requires exclusively MyD88 for NF- $\mathrm{kB}$ activation [10]. It is well documented that the biglycan protein core is solely responsible for the high affinity binding of this proteoglycan to TLR2 and TLR4 [11]. On the other hand, only fully glycanated intact biglycan, consisting of the protein core and two glycosaminoglycan side chains, is capable of inducing TLR2 and TLR4 signaling [5,8]. The structural motifs of biglycan protein and the adapter molecules involved in these interactions need further investigations. By selective engagement of TLRs and their adaptor molecules biglycan tightly regulates inflammatory outcome $[6,7,11,12]$. Accordingly, biglycan-induced recruitment of macrophages to the kidney depends on biglycan-triggered transcription and secretion of macrophage chemoattractants, chemokine (C-C motif) ligand CCL2 and CCL5 [4-6,9,13,14]. Previously, we showed that circulating biglycan evokes the production of CCL2 in a TLR2/4/MyD88-dependent manner, whereas the production of CCL5 was TLR4/TRIF dependent [6]. The interactions between biglycan and different receptors $[3,4]$ orchestrate the recruitment of macrophages to inflamed tissues under disease conditions such as in lupus nephritis [9] and renal ischemia-reperfusion injury [11,15]. However, to date, the exact molecular mechanism through which biglycan-induced TLR2/TLR4/MyD88 and TLR4/TRIF pathways lead to the production of CCL2 and CCL5 remain elusive.

There is growing evidence that sphingolipid signaling plays an essential role in the modulation of various inflammatory pathways [16]. Sphingosine kinases (SphK)s, with the two isoforms SphK1 and -2 , are enzymes, which catalyze the adenosine triphosphate (ATP)-dependent phosphorylation of sphingosine (Sph) to produce sphingosine 1-phosphate (S1P) $[17,18]$. S1P is implicated in cellular processes such as cell survival, proliferation, differentiation, migration, and immune function [18]. Given these roles of S1P, the sphingosine kinases activity is a target in many pathological conditions such as atherosclerosis, acute pulmonary injury, respiratory distress, tumorigenesis, and metastasis as well as inflammation [19].

In response to TNF $\alpha$ or IL-1 $\beta$, SphK1 is phosphorylated by Erk1/2, which increases its catalytic activity [20]. Furthermore, SphK1 and the production of S1P increase the activity of the TNF receptor-associated factor 2 (TRAF2) E3 ubiquitin ligase, receptor-interacting protein 1 (RIP1) polyubiquitination and further NF- $\mathrm{KB}$ activation [21]. This potentiates the expression of chemokine (C-X-C motif) ligand (CXCL) 10 and CCL5 resulting in the recruitment of the mononuclear cells to the site of inflammation [22]. Moreover, lipopolysaccharides (LPS) induce SphK1 activation via TLR4 in macrophages, thereby promoting IL-6 generation [23]. Targeting SphK1 in mice by genetic ablation or pharmacological inhibition ameliorates the inflammatory cytokine production as well as the pathogenesis of experimental models of arthritis [24,25], hepatitis [26], and pulmonary fibrosis [27]. 
Based on these reports, it is tempting to speculate that there is a reciprocal interference between biglycan and sphingolipid signaling in the regulation of inflammation.

Here we demonstrate for the first time that there is crosstalk between the ECM-derived component biglycan and SphK1-driven lipid signaling. We show that soluble biglycan enhances the expression and activity of SphK1 via the TLR4/TRIF pathway in mouse primary macrophages. Biglycan-induced SphK1 activity is essential for the production of CCL2 and CCL5 chemoattractants. Importantly, we prove this concept in vivo in soluble biglycan-overexpressing mice deficient for SphK1. Thus, targeting SphK1 may represent a potential therapeutic strategy in biglycan-evoked sterile inflammation.

\section{Results}

\subsection{Biglycan Triggers the Expression and Activity of Sphk1 in Mouse Peritoneal Macrophages}

To address the potential interference between biglycan and sphingolipid signaling in inflammation, thioglycolate-elicited primary macrophages isolated from wild-type (WT) C57BL/6 mice were stimulated with recombinant intact biglycan consisting of the protein core and two glycosaminoglycan side chains $(4 \mu \mathrm{g} / \mathrm{mL})$. After $30 \mathrm{~min}$ of incubation with biglycan already a significant increase in Sphk1 mRNA level was detected with time-dependent, consecutive Sphk1 expression enhancement up to five-fold after $6 \mathrm{~h}$ (Figure 1a, shown at $6 \mathrm{~h}$ of incubation).

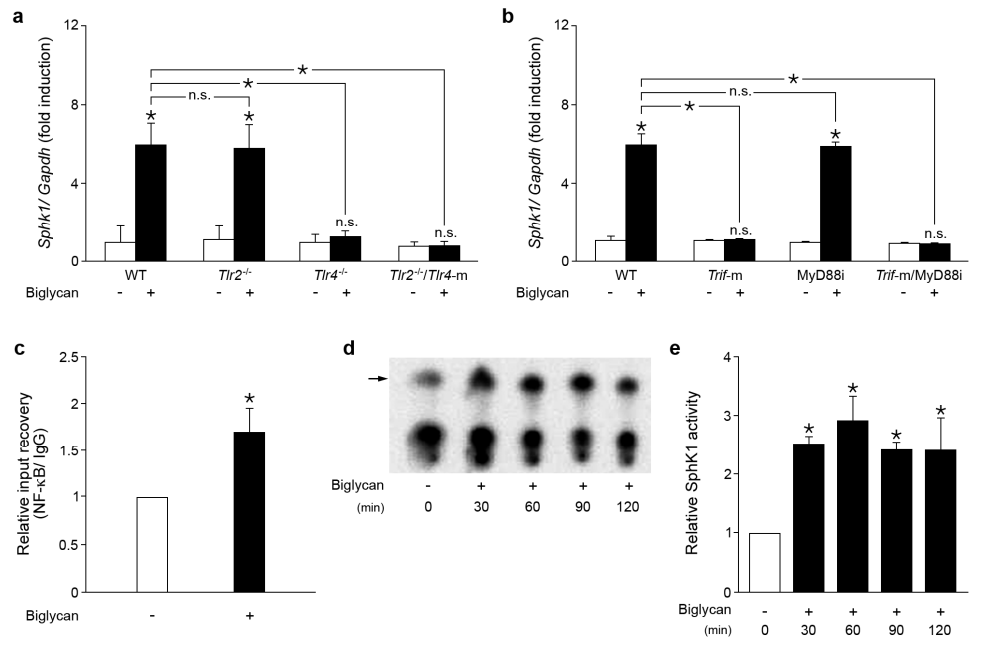

Figure 1. Biglycan triggers Sphk1 mRNA expression via TLR4/TRIF/NF-kB and stimulates SphK1 activity in macrophages. (a,b) qPCR analysis of Sphk1 normalized to Gapdh mRNA levels in biglycan-stimulated $\left(4 \mu \mathrm{g} / \mathrm{mL}, 6 \mathrm{~h}\right.$ ): (a) WT, Tlr2 $2^{-/}$, Tlr $4^{-/-}$and Tlr2 $2^{-/} / \mathrm{Tlr} 4-\mathrm{m}$ macrophages; and (b) WT and Trif-m macrophages pre-incubated with MyD88 inhibitor (50 $\mu \mathrm{M}, 30 \mathrm{~min})$. (c) Chromatin immunoprecipitation with anti-NF-kB p65 antibody in WT macrophages stimulated with biglycan for 60 min followed by qPCR for Sphk1. The PCR primers bind at the transcription start site (TSS) or the promoter region. ChIP-qPCR analysis was normalized to IgG and given as fold induction of untreated control. (d) SphK activity assay based on sphingosine phosphorylation in the presence of $\left[\gamma^{-32} \mathrm{P}\right]$ ATP in WT macrophages stimulated with biglycan for 30, 60, 90 and 120 min. Product separation was performed by TLC and detection with PharosFX Plus Molecular Imager (Bio-Rad, Munich, Germany). Arrow indicates $\left[\gamma^{-32}\right.$ P] S1P. (e) Quantification of the resulting bands in (d). Data are expressed as means \pm standard deviation (SD). (a,b) $n=5$ individual experiments; (c,d,e) $n=3$ individual experiments; ${ }^{*} p<0.05$; n.s. = not significant. TLR: toll-like receptor; TRIF: Toll/IL-1R domain-containing adaptor inducing interferon (IFN)- $\beta$; NF- $\kappa$ B: nuclear factor $\kappa$-light-chain-enhancer of activated B-cells; SphK1: sphingosine kinase 1; qPCR: quantitative real-time polymerase chain reaction; ChIP: chromatin immunoprecipitation; WT: wild type; IgG: immunoglobulin G; MyD88: myeloid differentiation primary response protein; ATP: adenosine triphosphate; TLC: thin layer chromatography; S1P: sphingosine-1 phosphate; Gapdh: Glyceraldehyde 3-phosphate dehydrogenase. 
Next, the receptor and adaptor molecules involved in biglycan-induced Sphk1 expression were investigated, using WT, Tlr2 $2^{-/-}$, Tlr $4^{-/-}$and Tlr2 ${ }^{-/-} / \mathrm{Tlr} 4-\mathrm{m}$ macrophages. Quantitative real-time polymerase chain reaction (PCR) analysis revealed a similar level of Sphk1 mRNA in WT and Tlr2-/macrophages in response to biglycan, but no increase in $T l r 4^{-/-}$and Tlr2 ${ }^{-/-} / \mathrm{Tl} 4$-m macrophages (Figure 1a). Thus, biglycan signals through the TLR4 to induce Sphk1 mRNA expression.

To identify the TLR4 adaptor molecule involved in biglycan-dependent Sphk1 overexpression, macrophages from WT and Trif-m mice were pre-incubated for 30 min with the MyD88 inhibitor $(50 \mu \mathrm{M})$ prior to stimulation with biglycan. Dysfunctional mutation of TRIF protein completely abolished biglycan induced Sphk1 expression, whereas the MyD88 inhibitor had no influence on its expression (Figure 1b). The functionality of the MyD88 inhibitor was proven by its inhibitory effects on biglycan-dependent induction of TNF $\alpha$, as described previously [7]. To further demonstrate whether NF- $\mathrm{KB}$ is involved in biglycan/TLR4/TRIF induction of Sphk1, a chromatin immunoprecipitation (ChIP) assay was performed. Indeed, stimulation with biglycan (30-120 min) potentiated direct interaction between the NF- $\mathrm{kB}$ p 65 subunit and the transcription start site (TSS) in WT macrophages (Figure 1c, shown at $60 \mathrm{~min}$ of incubation).

Next, we investigated whether biglycan is capable of inducing SphK1 activity in macrophages. In fact, 30-120 min of stimulation with biglycan resulted in a 2-3-fold enhancement of SphK1 activity in WT macrophages (Figure 1d,e). Collectively, we demonstrated that biglycan triggers via TLR4/TRIF/NF- $k B$ the activity of Sphk1 in murine macrophages.

\subsection{Sphk2 Deficiency Potentiates Biglycan Triggered Sphk1 mRNA Expression}

In the next set of experiments, the influence of biglycan on the expression of the sphingosine kinase isoform Sphk2 was investigated. Biglycan had no effect on Sphk2 mRNA expression in WT macrophages during 30 min-6 h of incubation (Figure 2a, shown at $2 \mathrm{~h}$ of incubation).
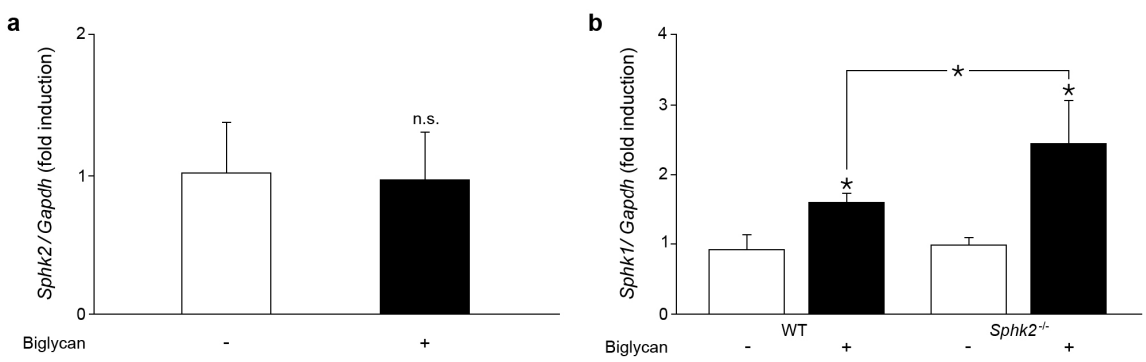

Figure 2. Sphk2 deficiency potentiates biglycan-triggered Sphk1 mRNA expression. (a,b) qPCR analysis for mRNA levels of: (a) Sphk2 in WT macrophages stimulated with biglycan $(4 \mu \mathrm{g} / \mathrm{mL}, 2 \mathrm{~h})$; and (b) Sphk1 in WT and Sphk2-/- macrophages stimulated with biglycan $(4 \mu \mathrm{g} / \mathrm{mL}, 2 \mathrm{~h})$. mRNA expression was normalized to Gapdh and given as fold induction of untreated WT controls. Data are expressed as means \pm SD. (a) $n=5$ individual experiments; (b) $n=3$ individual experiments; ${ }^{*} p<0.05$; n.s. = not significant.

In various cell types, deficient of Sphk2, a compensatory overexpression of Sphk1 mRNA has been reported $[27,28]$. Indeed, Sphk $2^{-1-}$ macrophages stimulated with biglycan for $2 \mathrm{~h}$ revealed a marked overexpression of Sphk1 mRNA (Figure 2b). Taken together, biglycan selectively upregulates Sphk1 expression in macrophages and this is more pronounced when SphK2 is lacking. Therefore, in the following experiments biglycan-stimulated Sphk2 ${ }^{-/}$macrophages were considered as Sphk1 overexpressing cells.

\subsection{Biglycan Triggers CCL2 and CCL5 Production in a SphK1-Dependent Manner}

Previously, we have shown that biglycan triggers production of macrophage chemoattractants CCL2 and CCL5 [5-7,9]. As SphK1 modulates expression of various chemoattractants $[23,29,30]$, 
we addressed the issue whether SphK is involved in biglycan-triggered production of CCL2 and CCL5. Indeed, Sphk1 deficiency resulted in a marked reduction of biglycan-triggered Ccl2 mRNA expression in macrophages at $2 \mathrm{~h}$ of incubation (Figure 3a).
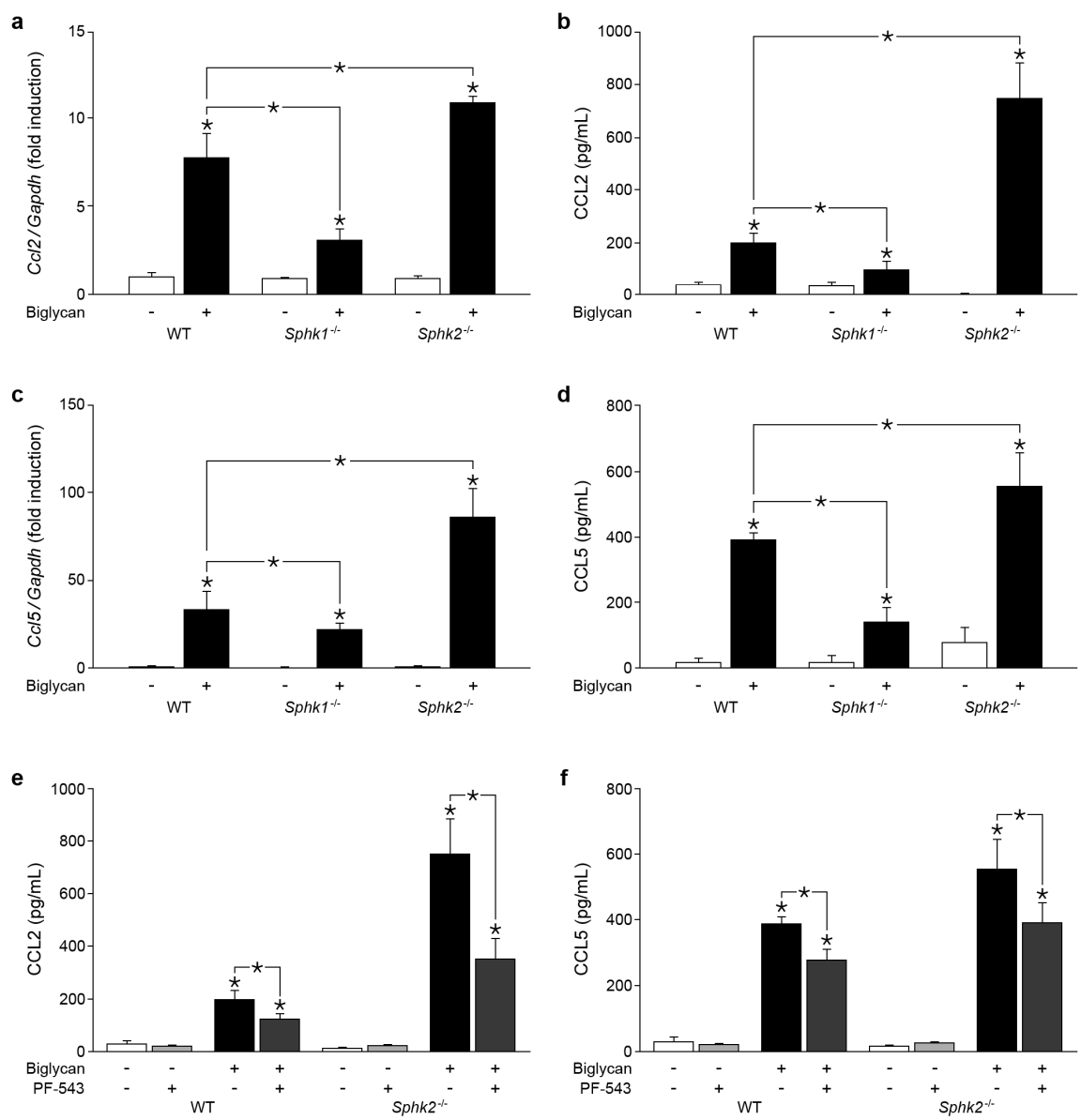

Figure 3. Biglycan triggers chemokine (C-C motif) ligand (CCL) 2 and CCL5 production via SphK1 in macrophages. (a,c) qPCR analysis of mRNA levels of: (a) Ccl2; and (c) Ccl5 in WT, Sphk1-/-, and Sphk2 $2^{-/}$macrophages stimulated with biglycan $(4 \mu \mathrm{g} / \mathrm{mL}, 2 \mathrm{~h})$. (b,d) Enzyme Linked Immunosorbent Assay (ELISA) for: CCL2 (b); and CCL5 (d) in the supernatants of WT, Sphk1-/- and Sphk2 ${ }^{-/-}$ macrophages stimulated with biglycan $(4 \mu \mathrm{g} / \mathrm{mL}, 2 \mathrm{~h}$ for CCL2 and $6 \mathrm{~h}$ for CCL5). (e,f) ELISA for: CCL2 (e); and CCL5 (f) in the supernatants of WT and Sphk2-/- macrophages stimulated with biglycan $(4 \mu \mathrm{g} / \mathrm{mL}, 2 \mathrm{~h}$ for CCL2 and $6 \mathrm{~h}$ for CCL5) with and without the SphK1 inhibitors PF-543 (100 nM) applied $30 \mathrm{~min}$ prior to biglycan stimulation. mRNA expression was normalized to Gapdh and given as fold induction of untreated WT control. Data are expressed as means \pm SD. (a-f) $n=3$ individual experiments; ${ }^{*} p<0.05$.

These data were further confirmed by decreased CCL2 protein abundance in cell supernatants from $S p h k 1^{-/-}$macrophages after $6 \mathrm{~h}$ of incubation with soluble biglycan (Figure 3b). By contrast, in Sphk2-/macrophages overexpressing Sphk1 biglycan markedly induced Ccl2 mRNA expression (Figure 3a) resulting in enhanced CCL2 protein levels (Figure 3b). A similar pattern of biglycan/SphK1-dependent mRNA (Figure 3c) and protein (Figure 3d, shown at $6 \mathrm{~h}$ of incubation) regulation was obtained for CCL5.

To provide direct proof that biglycan-driven overexpression of CCL2 and CCL5 in cells lacking SphK2 is caused by SphK1, WT and Sphk2 $2^{-/}$, macrophages were incubated with biglycan in the presence of PF-543, a specific inhibitor of the SphK1 enzymatic activity [31,32]. As expected, this inhibitor reduced biglycan-dependent enhancement of CCL2 (Figure 3e) and CCL5 (Figure 3f) 
protein levels in supernatants from WT cells and abolished the chemokine overproduction in Sphk $2^{-1-}$ macrophages.

Thus, we provide here genetic and pharmacological proof that SphK1 is a crucial downstream mediator of biglycan-triggered CCL2 and CCL5 mRNA and protein expression in macrophages.

\subsection{Biglycan Triggers Expression of Ccl2 via NF- $k B$, Erk1/2 and p38 MAPK, While Ccl5 Expression is Induced through NF- $\mathrm{KB}$ and p38 MAPK}

Our previous results demonstrated that biglycan induces the production of CCL2 in a TLR2/4/MyD88- and in the case of CCL5 in a TLR4/TRIF-dependent manner [6]. However, the gap in the signaling pathway between the adaptor and effector molecules had not been characterized. Therefore, we aimed to identify the kinase, which would be responsible for biglycan-, TLR2/4/MyD88-, and biglycan-TLR4/TRIF-triggered synthesis of CCL2 and CCL5, respectively. It is known that biglycan activates phosphorylation of Erk1/2, p38 MAPK and the translocation of NF- $\mathrm{KB}$ in macrophages [5]. Thus, we applied U0126, SB203580 and the IкB kinase (IKK) inhibitor III, the inhibitors of mitogen-activated protein kinase Erk kinase (MEK), p38 MAPK, and IкB kinase to WT macrophages for verification. Inhibition of IKK, Erk1/2 and p38 MAPK markedly reduced the biglycan-triggered Ccl2 mRNA expression (Figure 4a). In contrast, biglycan-dependent Ccl5 mRNA expression was reduced exclusively via IKK and p38 MAPK inhibitor (Figure 4b).
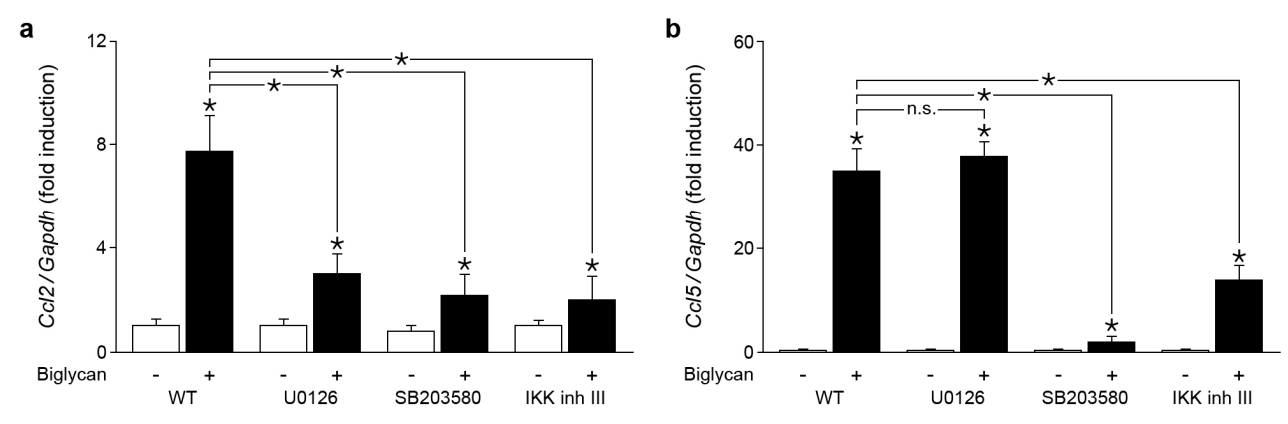

Figure 4. Biglycan triggers expression of $\mathrm{Ccl} 2$ and $\mathrm{Ccl} 5$ mRNA in Erk1/2-, p38 MAPK and NF-kB-dependent manner. (a,b) qPCR analysis for mRNA levels of: (a) Ccl2; and (b) Ccl5 in WT macrophages stimulated with biglycan $(4 \mu \mathrm{g} / \mathrm{mL}, 2 \mathrm{~h})$ with and without MEK/Erk inhibitor U0126 $(10 \mu \mathrm{M})$, p38 MAPK inhibitor SB203580 $(10 \mu \mathrm{M})$, and IKK inhibitor III $(10 \mu \mathrm{M})$. The inhibitors were applied $30 \mathrm{~min}$ prior to the biglycan stimulation. mRNA expression was normalized to Gapdh and given as fold induction of untreated WT controls. Data are expressed as means \pm SD. $n=3$ individual experiments; ${ }^{*} p<0.05 ;$ n.s. $=$ not significant. Erk1/2: extracellular signal-regulated kinase; p38 MAPK: p38 mitogen-activated protein kinase; IKK: IкB kinase; inh: inhibitor.

Thus, biglycan stimulates Ccl2 expression via TLR2/4/MyD88 and downstream activation of NF-kB, Erk1/2 and p38 MAPK, while Ccl5 expression is triggered by biglycan through TLR4/TRIF/NF- $\mathrm{KB}$ and $\mathrm{p} 38$ MAPK.

\subsection{Control of Biglycan-Dependent Erk1/2, p38 MAPK and NF-kB Subunit p65 by SphK1 in Macrophages}

As Erk1/2, p38 MAPKs, NF- $\mathrm{kB}$, and SphK1 are mediators of the biglycan-triggered production of CCL2 and CCL5 chemokines, we evaluated whether SphK1 affects Erk1/2, p38 MAPK and NF- $\mathrm{KB}$ subunit 65 phosphorylation. In agreement with previous data, Western blot analysis demonstrated the phosphorylation of Erk1/2 (Figure 5a), p38 MAPK (Figure 5c) and p65 (Figure 5e) in WT macrophages incubated with biglycan for $30 \mathrm{~min}$, which is a peak for biglycan stimulation of both Erk1/2 and p38 MAPK [5,7]. However, much less Erk1/2 (Figure 5a,b), p38 MAPK (Figure 5c,d) and p65 (Figure 5e,f) were found to be phosphorylated in biglycan-stimulated $S p h k 1^{-/-}$macrophages. 
a

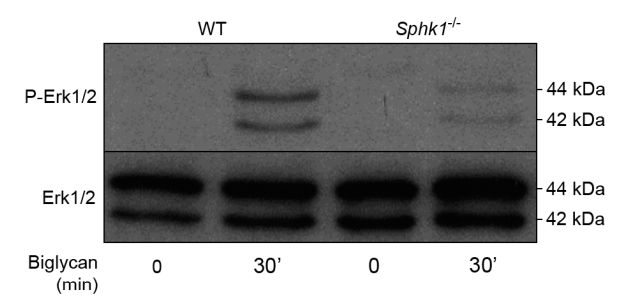

c

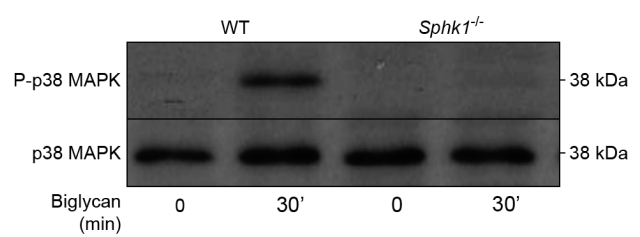

$(\min )$

e

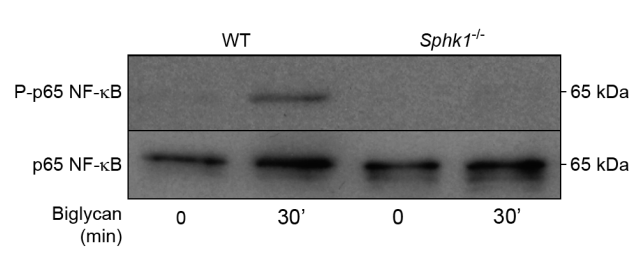

b
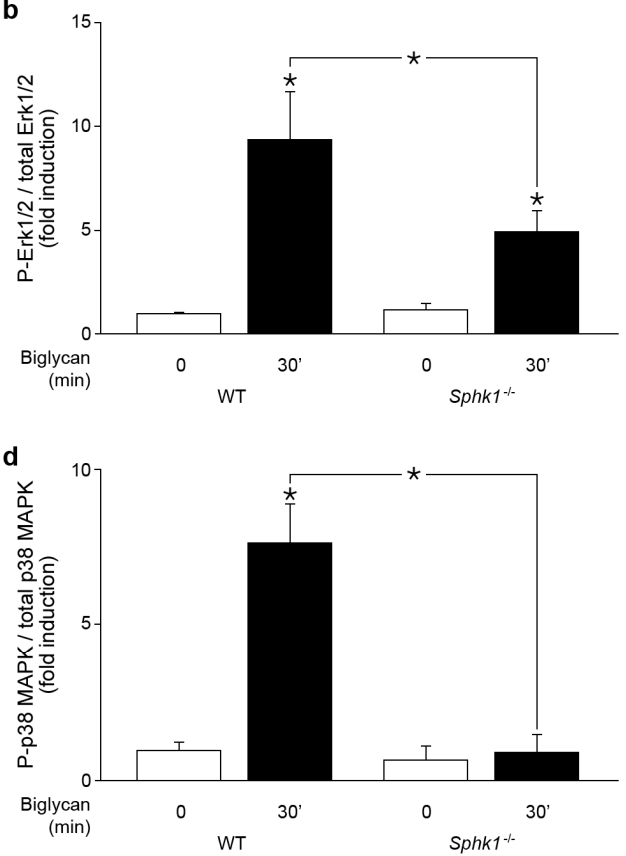

f

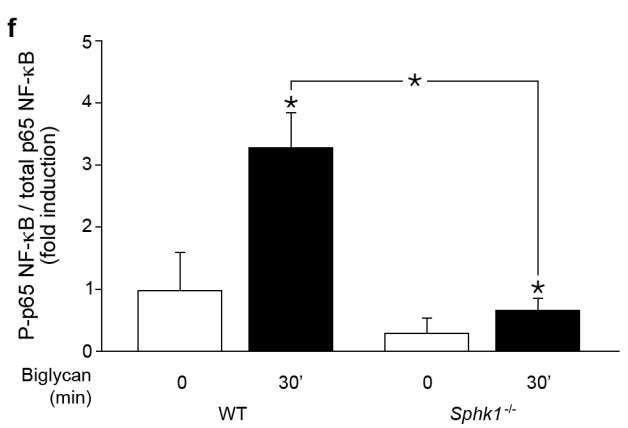

Figure 5. Biglycan phosphorylates Erk1/2, p38 MAPK and NF- $\mathrm{B}$ p65 in SphK1-dependent manner in macrophages. (a,c,e) Western blot analysis of: (a) Erk1/2 phosphorylation; (c) p38 MAPK phosphorylation; and (e) NF- $\mathrm{kB}$ p65 phosphorylation in WT and Sphk1-/- macrophages stimulated with biglycan $(4 \mu \mathrm{g} / \mathrm{mL}, 30 \mathrm{~min})$. (b,d,f) Quantification of the resulting bands in (a,c,e), respectively, normalized to: (a) total Erk; (c) total p38; and (e) total p65. Data are expressed as means \pm SD. $n=3$ individual experiments; ${ }^{*} p<0.05$.

These data show that biglycan-induced phosphorylation of Erk1/2, p38 MAPK and p65 is SphK1-dependent. Thus, biglycan triggers CCL2 and CCL5 production in macrophages through SphK-controlled activation of Erk1/2, p38 MAPKs and NF-kB.

2.6. Soluble Biglycan Triggers Renal Expression of Ccl2 and Ccl5 and Macrophage Recruitment into the Kidney in Sphk1-Dependent Manner

To address the in vivo relevance of these findings, human biglycan (pLIVE-hBGN) or empty pLIVE vector were transiently expressed (3 days) in WT, Sphk1-/- and Sphk2-/- murine livers under an albumin promoter [6,9]. Following transfection, soluble biglycan is released into the bloodstream and accumulates in various organs e.g., in the kidney [6,9]. Overexpression of human biglycan in the liver was confirmed by qPCR and restriction fragment length polymorphism analysis (data not shown) as described previously [6,9]. Plasma and renal levels of human biglycan were verified by Western blots [6,9]. As expected from our previous results, the Ccl2 (Figure 6a) and Ccl5 (Figure 6b) mRNA expression was elevated in WT pLIVE-hBGN vs. control pLIVE-kidneys [6]. 
a

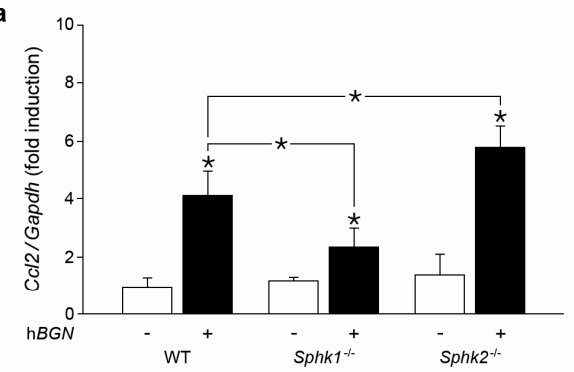

C

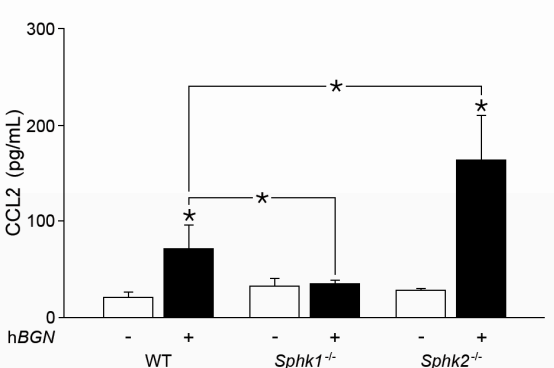

e

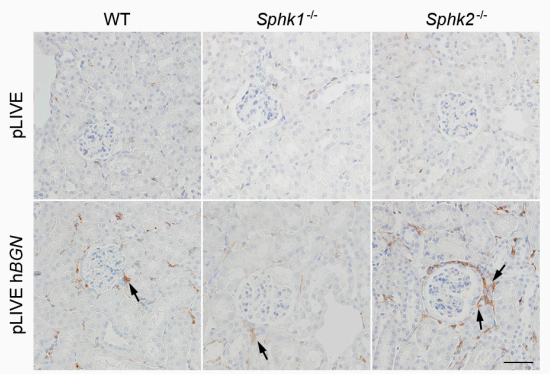

b
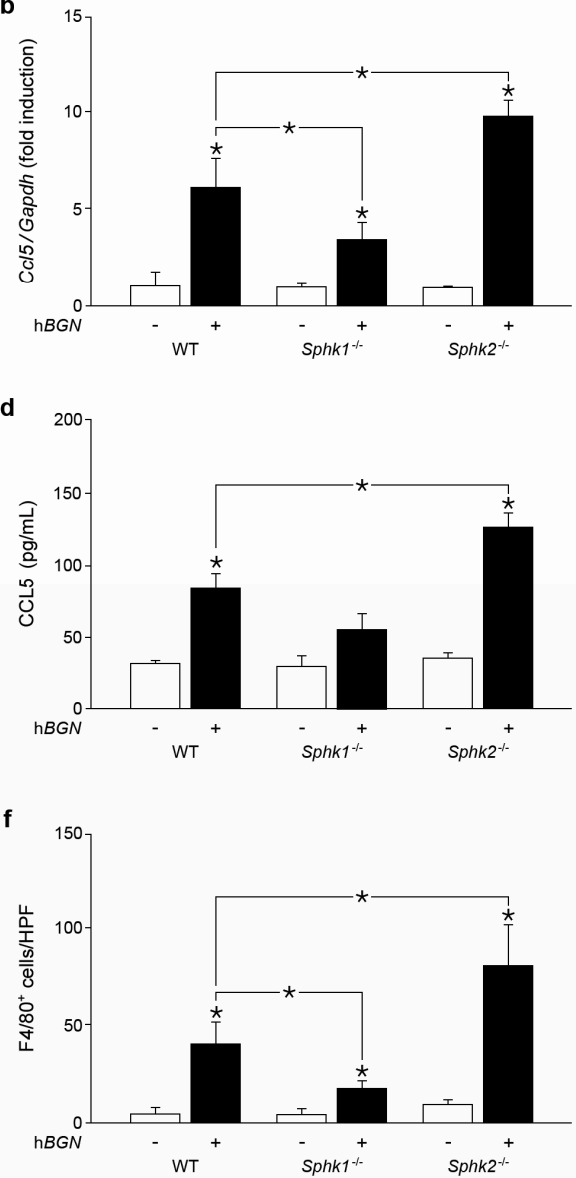

Figure 6. Biglycan induces $\mathrm{Ccl} 2$ and $\mathrm{Ccl} 5$ expression through SphK1 leading to renal recruitment of macrophages. (a,b) qPCR analysis of renal: (a) Ccl2; and (b) Ccl5 mRNA expression levels in pLIVE-hBGN and pLIVE (control) WT, Sphk1 $1^{-/}$and $S p h k 2^{-/-}$mice, three days of transfection. mRNA expression was normalized to Gapdh and given as fold induction of pLIVE-treated WT controls. (c,d) Plasma levels of: CCL2 (c); and CCL5 (d) in WT, Sphk1 $1^{-/}$, and Sphk2 ${ }^{-/}$mice, 3 days of transfection. (e) Immunohistochemical staining of the F4/80 macrophage marker (brown, depicted by arrows) in renal sections of WT, Sphk1 $1^{-/}$, and Sphk2-/- mice after injection of pLIVE-hBGN or pLIVE control, three days of transfection. Scale bar: $50 \mu \mathrm{m}$. (f) Quantification of F4/80 cells given as cell count per high-power field (HPF). Data are expressed as means \pm SD. $n=3$ mice per group; ${ }^{*} p<0.05$.

Importantly, biglycan-dependent induction of renal Ccl2 (Figure 6a) and Ccl5 (Figure 6b) mRNA expression significantly declined in transfected pLIVE-hBGN Sphk1-deficient vs. pLIVE-hBGN WT mice. On the contrary, the expression of both chemokines was markedly enhanced in Sphk2-deficient pLIVE-hBGN as compared to pLIVE-hBGN WT kidneys (Figure 6a,b). This was associated with reduced plasma levels of CCL2 (Figure 6c) but not of CCL5 (Figure 6d) in pLIVE-hBGN Sphk1-/- mice and enhanced concentrations of circulating CCL2 (Figure 6c) and CCL5 (Figure 6d) in pLIVE-hBGN Sphk2-/- vs. WT transfected animals.

In addition, immunostaining for the macrophage marker F4/80 in renal sections from pLIVE-hBGN-injected mice revealed a lower number of macrophages in Sphk1-/- mice compared to WT (Figure 6e,f). On the other hand, enhanced macrophage infiltration was found in kidney sections from pLIVE-hBGN-transfected Sphk2-/- vs. WT kidneys (Figure 6e,f).

Thus, biglycan triggers expression of $\mathrm{Ccl} 2$ and $\mathrm{Ccl} 5$ and the recruitment of macrophages into the kidney in a Sphk1-dependent manner. 


\section{Discussion}

The present report reveals sphingosine kinase SphK1 as a key contributor to the biglycan-driven inflammatory response in macrophages. Here we show that the ECM proteoglycan biglycan promotes the expression and activity of SphK1 through TLR4/TRIF/NF- $\mathrm{kB}$ and thus induces the production of the inflammatory chemoattractants CCL2 and CCL5 in macrophages. Biglycan triggers the synthesis and activity of SphK1 in a selective manner having no effect on the regulation of the SphK2 isoform. Mechanistically, biglycan potentiates the production of CCL2 via TLR2/TLR4/MyD88/Erk1/2/p38 MAPK/NF-KB and CCL5 via TLR4/TRIF/p38 MAPK/NF- KB in a SphK1-dependent manner, ultimately leading to the recruitment of macrophages into the kidney. The underlying mechanisms are graphically presented in Figure 7.

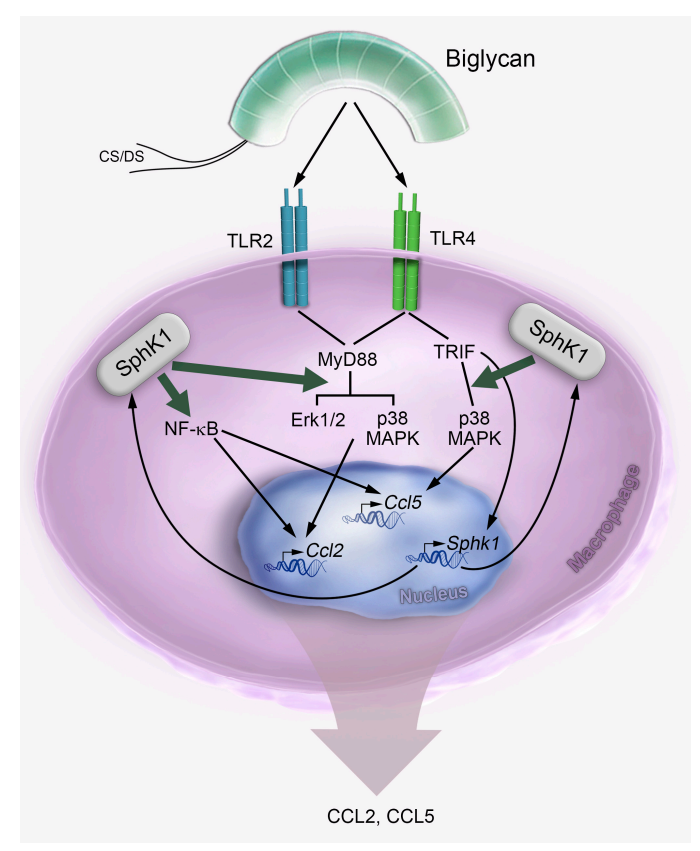

Figure 7. A working model summarizing the mechanisms of biglycan-driven and Sphk1-mediated production of macrophage chemoattractants CCL2 and CCL5. Following release from the ECM, biglycan interacts with TLR2 and -4 and triggers production of CCL2 and CCL5 through TLR2/4/MyD88 and TLR4/TRIF, respectively. By signaling via TLR4, biglycan induces the Sphk1 synthesis in a TLR4/TRIF-dependent manner. Moreover, biglycan induces the activity of SphK1. In turn, active SphK1 drives the biglycan-mediated production of CCL2 through Erk1/2 p38 MAPK and NF- $\mathrm{B}$ activation, while CCL5 is induced only through p38 MAPK and NF- $\mathrm{KB}$ activation. Consequently, this leads to the recruitment of macrophages to inflamed tissues. Green arrows underline the effect of SphK1 on the biglycan-promoted NF- $\mathrm{B}$ activation, MyD88/Erk1/2/p38 MAPK and TRIF/p38 MAPK pathways. Black arrows describe the biglycan-mediated inflammatory cascade.

This is the first study showing that a component of the sphingolipid signaling network SphK1 is directly triggered by the ECM component biglycan. Diverse factors, such as TNF $\alpha$ [20,33,34], IL-1 $\beta$ [35], platelet-derived growth factor (PDGF) [36], transforming growth factor (TGF $\beta$ ) [37,38], and nerve growth factor [39] have been reported to regulate SphK1. Among those factors, TGF $\beta$ and PDGF are not induced by biglycan [40,41]. By contrast, it is well known that biglycan acts as a trigger of TNF $\alpha$ and IL-1 $\beta$ protein in macrophages, requiring at least two hours of stimulation before the cytokines can be detected $[5,9,37]$. It is of note that biglycan-induced synthesis and activity of SphK1 as well as the interaction between NF-KB and Sphk1 TSS occur already after $30 \mathrm{~min}$. Therefore, it is conceivable that biglycan directly triggers SphK1 expression. At later time points, biglycan-induced TNF $\alpha$ and IL-1 $\beta$ 
might potentiate the direct effects of biglycan on SphK1 production. Hence, our data strongly suggest that biglycan directly induces SphK1 synthesis and activity.

Our findings regarding biglycan-dependent $S p h k 1$ induction are in agreement with several reports describing sphingosine kinases and sphingolipid metabolites to be involved in inflammatory reactions in response to various sterile danger signals or pathogens $[17,33]$. There are extensive studies, which show promoting effects of SphK1 on LPS- [20,23,42] and Mycobacterium smegmatis-triggered [43] expression of pro-inflammatory cytokines. Moreover, LPS cooperates with S1P to augment the expression of adhesion molecules and pro-inflammatory modulators [44]. S1P was shown to trigger cell death and NLR family pyrin domain containing 3 (NLRP3) inflammasome-dependent IL-1 $\beta$ secretion [30]. Additionally, sphingosine might act by itself as an endogenous DAMP [45].

Furthermore, we identified SphK1 as a crucial regulator of biglycan-dependent CCL2 and CCL5 production. Previously, we reported that soluble biglycan evokes CCL2 expression by engaging the TLR2/TLR4/MyD88 signaling pathway and CCL5 through TLR4/TRIF [6,7,9,11]. Here, we filled some of the signaling gaps between TLRs/ adaptor molecule complex and downstream cytokine synthesis. In macrophages genetically ablated or pharmacologically inhibited for SphK1, we discovered that SphK1 is a crucial mediator of biglycan-triggered Erk1/2, p38 MAPK, and NF-KB activation. Additionally, we found that biglycan triggers expression of Ccl2 through Erk1/2, p38 MAPK and NF-kB activation, while Ccl5 expression requires p38 MAPK and NF- $\mathrm{kB}$. Importantly, SphK1 is a common upstream mediator of biglycan-dependent Erk1/2 p38 MAPK and NF- $\mathrm{kB}$ as well as of CCL2 and CCL 5 synthesis. Thus, biglycan triggers the synthesis of SphK1 in macrophages in order to promote activation of Erk1/2, p38 MAPKs and NF- $\mathrm{kB}$. Notably, this also represents a positive regulatory acceleration loop where NF- $\mathrm{KB}$ is required for SphK1 upregulation, which, in turn, triggers NF- $\mathrm{KB}$ activation. The activation of NF- $\mathrm{KB}$ by SphK1 is still controversially discussed. On one hand, it was shown that in mouse embryonic fibroblasts, SphK1 deficiency abolished TNF $\alpha$-stimulated NF- $\mathrm{KB}$ activation [21], whereas, on the other hand, in macrophages of either Sphk1 deficient or myeloid-specific Sphk1/Sphk2 double deficient mice, no defect in TNF $\alpha$ - and LPS-induced inflammatory responses was detected, and these mice showed unaltered LPS-induced systemic inflammation and death [46].

Based on the literature and our data, it appears that SphK1 engages specific receptor/adapter molecule complexes, e.g., TLR4/MyD88 for LPS [47], TLR4/TRIF for biglycan, TLR2 for lipopeptides [48], and TNF receptor for TNF $\alpha$ [49] to stimulate the transcription of CCL2 and CCL5. Downstream of the receptors NF-kB [50] as well as various kinases such as Erk1/2 [23,51], protein kinase $\mathrm{C} \delta$ [34,52], phosphatidylinositol 3-kinase (PI3K) [23] or p38 MAPK were reported as mediators of CCL2 and CCL5 synthesis [43,44,51]. TNF $\alpha$ stimulates SphK1-mediated CCL5 through p38 MAPK [53], while Mycobacterium stimulates this cytokine through TLR2/SphK1 in a PI3K, Akt and IKK $\alpha / \beta$-dependent fashion [54,55]. Taken in account a broad range of stimuli, receptors, adapter molecules, phosphorylation mediators as well as cell types, SphK1 appears to be a promising therapeutic target to regulate the macrophage CCL2 and CCL5 chemoattractants [56-58].

Our study has unveiled that biglycan selectively induces SphK1, whereas the sphingosine kinase isoform SphK2 expression remains unchanged upon biglycan stimulation. Additionally, biglycan-dependent SphK1 induction was more pronounced in Sphk2-deficient macrophages due to compensatory Sphk1 upregulation. Consequently, higher CCL2 and CCL5 expression was detected in Sphk2-/- macrophages upon biglycan stimulation. Furthermore, the selective inhibitor of SphK1 activation [31] rescued the Sphk1-driven production of CCL2 and CCL5 in Sphk2 ${ }^{-1-}$ macrophages. This is in accordance with previous reports showing an inversed regulatory pattern of the Sphk1 and Sphk2 gens in various cell types and inflammatory disease models $[24,53,59,60]$. Furthermore, SphK1 but not SphK2-mediated S1P accelerates CCL2 expression in mast cells [61]. Thus, our findings provide strong evidence that biglycan selectively utilizes SphK1 to trigger CCL2 and CCL5 synthesis.

Importantly, we provided an in vivo proof of biglycan-SphK1-dependent CCL2 and CCL5 synthesis and macrophage recruitment. As previously described, transient overexpression of soluble biglycan $[6,7,9,11]$ resulted in higher renal Ccl2 and Ccl5 expression as well as in enhanced numbers of 
infiltrating macrophages in the kidney [6,9]. Accordingly, the renal expression of both chemokines and the number of macrophages were markedly reduced in Sphk1-/- mice and abundant in kidneys lacking Sphk2 vs. WT kidneys. Even though, there are no data addressing biglycan and sphingolipid interaction directly, SphKs and S1P have been studied in several renal diseases associated with overexpression of biglycan [11,62-64], namely diabetic nephropathy [65,66], glomerulonephritis [67], fibrosis [68], nephroblastoma [67] and acute kidney injury [69,70]. In this context, Sphk1 deficiency increases albuminuria and glomerular connective tissue growth factor expression in diabetic nephropathy [66,70]. However, it was also reported that SphK1 deficiency results in CCL2 reduction and prevention of renal fibrosis in diabetic nephropathy [65]. In renal ischemia reperfusion injury, however, overexpression of Sphk1 protects against inflammation and tubular damage [71]. Altogether, these data suggest that the effect of SphK1 on the outcome of renal inflammation is still controversial and appears to be diseaseand duration-dependent [16]. Here, we report an anti-inflammatory effect of Sphk1 deficiency in macrophage and kidney directly in a mouse model of transient overexpression of soluble biglycan.

In conclusion, we show for the first time that there is crosstalk between ECM- and sphingolipid-signaling. We have observed in vitro and in vivo evidence for biglycan-TLR4/TRIF-triggered SphK1 expression and activity. Our data provide new insights on how biglycan regulates CCL2 and CCL5 chemokines and macrophage recruitment into the kidney via SphK1. As SphK1 seems to impact on biglycan signaling upstream of Erk1/2, p38 MAPK and NF- $\mathrm{kB}$, it is conceivable that SphK1 is a general regulator of various biglycan-triggered inflammatory responses.

\section{Materials and Methods}

\subsection{Animal Experiments}

Eight- to twelve-week-old male wild-type C57BL/ 6 mice were purchased from Charles River Laboratories (Sulzfeld, Germany). Sphk1 ${ }^{-/-}$and Sphk2 $2^{-/-}$mice have been described previously $[28,65]$. Tlr2 $2^{-/}$and Tlr4 ${ }^{-/-}$mice were kindly provided by Marina Freudenberg (Max Planck Institute for Immunology, Freiburg, Germany). Tlr2 $2^{-/} / T l r 4-m$ mice (Tlr2 $2^{-/-}$mice carrying a TLR4 mutation) and Trif-m mice were a generous gift from Carsten Kirschning (Technical University of Munich, Munich, Germany) and Heinfried H. Radeke (University of Frankfurt, Frankfurt, Germany), respectively. All animal work was conducted in accordance with the German Animal Protection Law and was approved (F143/63, FU/K5591) by the Ethics Review Committee for laboratory animals of the District Government of Darmstadt, Germany.

\subsection{In Vivo Transfection}

Eight- to twelve-week-old wild-type C57BL/6, Sphk1 $1^{-/-}$and Sphk2-/- male mice were anesthetized with $2 \%$ isoflurane (Abbott, Wiesbaden, Germany) under $1 \mathrm{~L} /$ min oxygen supply. For intravenous delivery, $50 \mu \mathrm{g}$ of pLIVE-hBGN or pLIVE vector was incubated for $15 \mathrm{~min}$ before injection in sterile filtered 5\% glucose containing $6 \mu \mathrm{l}$ of Turbofect in vivo Transfection Reagent (Thermo Fisher Scientific, Darmstadt, Germany). The mice received a single intravenous injection and were sacrificed after 3 days of transfection. Plasma and liver were collected for analysis of $h B G N$ overexpression. Kidneys were subjected to RNA extraction, Western blotting and histological analysis.

\subsection{Immunohistochemistry}

Sections $(4 \mu \mathrm{m})$ of paraffin-embedded kidney samples from mice were blocked with $5 \%$ milk in Tris-buffered saline (TBS) with $0.05 \%$ Tween 20 for $1 \mathrm{~h}$ and incubated with the primary rat anti-mouse F4/80 (MCA497, Bio-Rad, AbDSerotec, Puchheim, Germany) antibody for $2 \mathrm{~h}$ at room temperature. The staining was developed with 3,3'-diaminobenzidine (Vector Laboratories, Peterborough, UK). Counterstaining was performed with Mayer's Hematoxylin (AppliChem GmbH, Darmstadt, Germany). The specificity controls included omitting or replacement of primary antibody with rat unspecific IgG. The number of macrophages was estimated per high-power field (HPF 400×, 
with a minimum of 7 fields counted) (Soft Imaging System, Olympus, Münster, Germany). Histological examinations were performed by two observers blinded to the conditions.

\subsection{Cell Culture and Stimulation}

Thioglycolate-elicited macrophages were isolated from peritoneal lavage of wild-type C57BL/6,

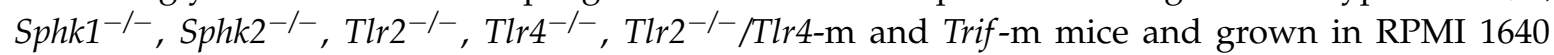
(Life Technologies, Darmstadt, Germany) supplemented with $1 \%$ penicillin and streptomycin and $2 \%$ fetal bovine serum (Biochrom, Berlin, Germany). Cells were stimulated with $4 \mu \mathrm{g} / \mathrm{mL}(80 \mathrm{nM})$ purified human biglycan [7] in serum-free medium for the indicated time points. For purification of the native proteoglycan, containing two chondroitin/dermatan sulfate chains, the conditioned medium of human biglycan-overexpressed 293 HEK cells was collected, passed over a DEAE-Trisacryl-M (Pall) column and further purified through high performance liquid chromatography [8]. The purity of the bigycan was verified by silver staining after sodium dodecyl sulfate (SDS) gel electrophoresis. MyD88 inhibitory peptide NBP2-29328 (50 $\mu \mathrm{M}$; Novus Biologicals, Wiesbaden, Germany) was applied $30 \mathrm{~min}$ prior to stimulation with biglycan. SphK1 inhibitor PF-543 (100 nM, Cayman Chemical, Hamburg, Germany), MEK inhibitor U0126 (10 $\mu$ M, Cell Signaling, Frankfurt am Main, Germany), p38 MAPK inhibitor SB203580 (10 $\mu \mathrm{M}$, Calbiochem, Darmstadt, Germany) and IKK inhibitor III (10 $\mu \mathrm{M}$, Merck, Darmstadt, Germany) were applied 30 min prior to stimulation with biglycan.

\subsection{RNA Isolation and Quantitative Real-Time PCR}

Total RNA was isolated using the TRI Reagent (Sigma Aldrich, Steinheim am Albuch, Germany) and was reverse transcribed using the High Capacity cDNA Reverse Transcription Kit (Applied Biosystems, Darmstadt, Germany). Real-time quantitative PCR was performed using AbiPrism 7500 Sequence Detection System (Applied Biosystem, Darmstadt, Germany). Quantitative RT-PCR was performed using TaqMan Fast Universal PCR Master Mix (Thermo Fisher Scientific, Darmstadt, Germany) and the following primers: Ccl2 (Mm00441242_m1), Ccl5 (Mm01302428_m1), Gapdh (Mm99999915_g1), Sphk1 (Mm01252547_g1) and Sphk2 (Mm00445021_m1). Relative changes in gene expression compared to control and normalized to Gapdh were quantified by the $2^{-\Delta \Delta \mathrm{Ct}}$ method.

\subsection{Chromatin Immunoprecipitation}

Preparation of cell extracts, crosslinking and isolation of nuclei was performed with the truCHIP ${ }^{\mathrm{TM}}$ Chromatin Shearing Kit (Covaris, Woburn, MA, USA) according to the manufacturers protocol. After sonification of the lysates with the Bioruptur Plus (10 cycles, $30 \mathrm{~s}$ on, $90 \mathrm{~s}$ off, $4{ }^{\circ} \mathrm{C}$; Diagenode, Seraing, Belgium), cell debris was removed by centrifugation and the lysates were diluted 1:3 in dilution

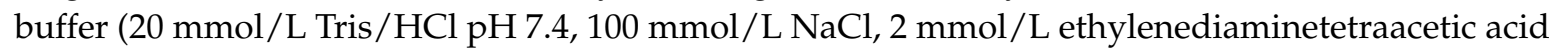
(EDTA), $0.5 \%$ Triton X-100 and protease inhibitors). Pre-clearing was done with $20 \mu \mathrm{L}$ DiaMag protein A coated magnetic beads slurry (Diagenode) for $45 \mathrm{~min}$ at $4{ }^{\circ} \mathrm{C}$. The samples were incubated over night at $4{ }^{\circ} \mathrm{C}$ with the antibodies against NF-KB (3 $\mu$ g Santa Cruz \#sc-109, Hedelberg, Germany) or IgG (3 $\mu$ g Diagenode \# c15410206). Five percent of the samples served as input. The complexes were collected with $35 \mu \mathrm{L}$ DiaMag protein A coated magnetic beads (Diagenode) for $3 \mathrm{~h}$ at $4{ }^{\circ} \mathrm{C}$, subsequently washed twice for $5 \mathrm{~min}$ with each of the wash buffers 1-3 (Wash Buffer 1:20 mmol/L Tris/ $\mathrm{HCl} \mathrm{pH} \mathrm{7.4,}$ $150 \mathrm{mmol} / \mathrm{L} \mathrm{NaCl}, 0.1 \%$ SDS, $2 \mathrm{mmol} / \mathrm{L}$ EDTA, 1\% Triton X-100; Wash Buffer 2:20 mmol/L Tris/HCl $\mathrm{pH} 7.4,500 \mathrm{mmol} / \mathrm{L} \mathrm{NaCl}, 2 \mathrm{mmol} / \mathrm{L}$ EDTA, 1\% Triton X-100; Wash Buffer 3:10 mmol/L Tris/HCl pH 7.4, $250 \mathrm{mmol} / \mathrm{L}$ lithium chloride, $1 \%$ Nonidet P-40, $1 \%$ sodium deoxycholate, $1 \mathrm{mmol} / \mathrm{L}$ EDTA) and finally washed with Tris-EDTA (TE)-buffer $\mathrm{pH}$ 8.0. Elution of the beads was done with elution buffer $(0.1 \mathrm{M} \mathrm{NaHCO} 3,1 \%$ SDS) containing $1 \times$ Proteinase $\mathrm{K}$ (Diagenode) and shaking at $600 \mathrm{rpm}$ for $1 \mathrm{~h}$ at $55^{\circ} \mathrm{C}, 1 \mathrm{~h}$ at $62{ }^{\circ} \mathrm{C}$ and $10 \mathrm{~min}$ at $95{ }^{\circ} \mathrm{C}$. After removal of the beads, the eluent was purified with the QiaQuick PCR purification kit (Qiagen, Hilden, Germany) and subjected to qPCR analysis. The following primer pairs for quantification of mouse Sphk1 were used: forward primer 5'-TGA CGC 
GTG CGG AAC CGC AGG-3' and reverse primer 5'-CTA TCT TCG CAT CGC TTC TTA AAG-3' for the TSS of Sphk1.

\subsection{Western Blot and ELISA}

Total kidneys as well as macrophages were lysed in buffer containing $50 \mathrm{mM}$ Tris $/ \mathrm{HCl}(\mathrm{pH} 8)$, $150 \mathrm{mM} \mathrm{NaCl}, 0.02 \% \mathrm{NaN}_{3}, 0.1 \% \mathrm{SDS}, 1 \mu \mathrm{g} / \mathrm{mL}$ aprotinin, $1 \%$ Nonidet $\mathrm{P}-40,0.5 \%$ sodium deoxycholate and protease inhibitors $(100 \mu \mathrm{g} / \mathrm{mL}$ phenylmethylsulfonyl fluoride, $0.1 \mathrm{M} \varepsilon$-amino-n-caproic acid, $13 \mu \mathrm{M}$ EDTA, $5 \mathrm{mM}$ benzammoniumchloride monohydrate and $10 \mathrm{mM} \mathrm{N}$-ethylmaleimide). For sodium dodecyl sulfate polyacrylamide gel electrophoresis (SDS-PAGE) and Western blotting, $50 \mu \mathrm{g}$ of total protein from each sample were mixed with loading buffer $(250 \mathrm{mM}$ Tris $/ \mathrm{HCl} \mathrm{pH} 6.8,8 \%$ sodium dodecyl sulfate, $40 \%$ glycerol, $8 \% \beta$-mercaptoethanol, $0.02 \%$ Bromo phenol blue) and boiled at $95^{\circ} \mathrm{C}$ for 5 min. Primary antibodies used were: mouse anti- $\beta$-actin (A5441, Sigma Aldrich, Steinheim am Albuch, Germany), rabbit anti-p38 MAPK (9212, Cell Signaling, Frankfurt am Main, Germany), rabbit anti-P-p38 MAPK (T180/Y182) (9211, Cell Signaling, Frankfurt am Main, Germany), rabbit anti-p44/42 MAPK (9102, Cell Signaling, Frankfurt am Main, Germany), rabbit anti-P-p44/42 MAPK (Thr202/Tyr204) (9101, Cell Signaling, Frankfurt am Main, Germany), rabbit anti-P-NF-kB p65 (Ser536) (93H1) (3033, Cell Signaling, Frankfurt am Main, Germany), and rabbit anti-NF-kB p65 (T180/Y182) (sc-109, Santa Cruz, Heidelberg, Germany). Secondary antibodies were HRP-coupled donkey anti-rabbit (NA934V, GE Healthcare, London, UK) and HRP-coupled sheep anti-mouse (NA931V, GE Healthcare, London, UK). Mouse CCL2/JE/MCP-1 and CCL5/RANTES DuoSet (R\&D Systems, Wiesbaden, Germany) ELISA kit was employed and followed according to the manufacturer's instructions.

\subsection{Determination of Sphingosine Kinase Activity}

Biglycan-stimulated primary murine macrophages were harvested and incubated with ice-cold $20 \mathrm{mM}$ Tris buffer ( $\mathrm{pH}$ 7.4) containing $20 \%$ glycerol, $1 \mathrm{mM} \beta$ mercaptoethanol, $1 \mathrm{mM}$ EDTA, phosphatase inhibitors ( $40 \mathrm{mM} \beta$-glycerophosphate, $1 \mathrm{mM}$ sodium orthovanadate, and $15 \mathrm{mM}$ sodium fluoride), protease inhibitors $(10 \mu \mathrm{g} / \mathrm{mL}$ leupeptin, $10 \mu \mathrm{g} / \mathrm{mL}$ aprotinin, and $1 \mathrm{mM}$ phenylmethylsulfonyl fluoride). The supernatant was assayed for sphingosine kinase activity by incubation with sphingosine (Sigma) and $\left[\gamma_{-}^{-32} \mathrm{P}\right]$ ATP for $15 \mathrm{~min}$ at $37^{\circ} \mathrm{C}$. The products were separated on a thin layer chromatography (TLC) plate using 1-butanol/ethanol/acetic acid/water (80:20:10:20) and visualized on PharosFX Plus Molecular Imager (Bio-Rad, Munich, Germany).

\subsection{Statistics}

All data are expressed as means \pm standard deviation (SD). Two-sided Student's $t$-test was used to evaluate significance of differences between groups. Differences were considered significant at $p<0.05$.

Acknowledgments: This study was supported by the German Research Council (SFB 815, project A5, SFB 1039, project B02, SFB 1177, project C2, and SCHA 1082/6-1), LOEWE program Ub-Net (all to Liliana Schaefer), German Research Council (WY119/1-3), German Center for Lung Research (to Malgorzata Wygrecka), and a young investigator grant in the Frankfurt Research Promotion Program (FFF) of the Medical Faculty, Goethe University Frankfurt (to Claudia Tredup). We thank Riad Haceni for a technical help.

Author Contributions: Louise Tzung-Harn Hsieh, Madalina-Viviana Nastase, Heiko Roedig, Jinyang Zeng-Brouwers, Chiara Poluzzi, Christian Fork, and Stephanie Schwalm performed the experiments; Louise Tzung-Harn Hsieh, Madalina-Viviana Nastase and Liliana Schaefer designed the research and analyzed the data; Stephanie Schwalm provided research materials and analyzing tools as well as analyzed the data. Claudia Tredup, Ralf P. Brandes, Malgorzata Wygrecka, Andrea Huwiler, Josef Pfeilschifter analyzed the data. Liliana Schaefer, Louise Tzung-Harn Hsieh and Madalina-Viviana Nastase wrote the paper. All of the authors provided final approval of the submitted and published versions.

Conflicts of Interest: The authors declare no conflict of interest. 


\section{Abbreviations}

$\begin{array}{ll}\text { CCL } & \text { chemokine (C-C motif) ligand } \\ \text { CXCL } & \text { chemokine (C-X-C motif) ligand } \\ \text { DAMP } & \text { damage-associated molecular patterns } \\ \text { ECM } & \text { extracellular matrix } \\ \text { IL-1 } & \text { interleukin-1 } \\ \text { LPS } & \text { lipopolysaccharide } \\ \text { MAPK } & \text { mitogen-activated protein kinase } \\ \text { MyD88 } & \text { myeloid differentiation primary response protein } \\ \text { NF-kB } & \text { nuclear factor k-light-chain-enhancer of activated B-cells } \\ \text { S1P } & \text { sphingosine-1 phosphate } \\ \text { SphK } & \text { sphingosine kinase } \\ \text { TLR } & \text { Toll-like receptor } \\ \text { TNF } & \text { tumor necrosis factor } \\ \text { TRIF } & \text { Toll/IL-1R domain-containing adaptor inducing IFN- } \beta \\ \text { TSS } & \text { transcription start site } \\ \text { WT } & \text { wild-type }\end{array}$

\section{References}

1. Schaefer, L. Complexity of danger: The diverse nature of damage-associated molecular patterns. J. Biol. Chem. 2014, 289, 35237-35245. [CrossRef] [PubMed]

2. Iozzo, R.V.; Schaefer, L. Proteoglycan form and function: A comprehensive nomenclature of proteoglycans. Matrix Biol. 2015, 42, 11-55. [CrossRef] [PubMed]

3. Moreth, K.; Iozzo, R.V.; Schaefer, L. Small leucine-rich proteoglycans orchestrate receptor crosstalk during inflammation. Cell Cycle 2012, 11, 2084-2091. [CrossRef] [PubMed]

4. Frey, H.; Schroeder, N.; Manon-Jensen, T.; Iozzo, R.V.; Schaefer, L. Biological interplay between proteoglycans and their innate immune receptors in inflammation. FEBS J. 2013, 280, 2165-2179. [CrossRef] [PubMed]

5. Schaefer, L.; Babelova, A.; Kiss, E.; Hausser, H.J.; Baliova, M.; Krzyzankova, M.; Marsche, G.; Young, M.F.; Mihalik, D.; Gotte, M.; et al. The matrix component biglycan is proinflammatory and signals through toll-like receptors 4 and 2 in macrophages. J. Clin. Investig. 2005, 115, 2223-2233. [CrossRef] [PubMed]

6. Zeng-Brouwers, J.; Beckmann, J.; Nastase, M.V.; Iozzo, R.V.; Schaefer, L. De novo expression of circulating biglycan evokes an innate inflammatory tissue response via Myd88/Trif pathways. Matrix Biol. 2014, 35, 132-142. [CrossRef] [PubMed]

7. Hsieh, L.T.; Frey, H.; Nastase, M.V.; Tredup, C.; Hoffmann, A.; Poluzzi, C.; Zeng-Brouwers, J.; Manon-Jensen, T.; Schroder, K.; Brandes, R.P.; et al. Bimodal role of NADPH oxidases in the regulation of biglycan-triggered IL-1 $\beta$ synthesis. Matrix Biol. 2016, 49, 61-81. [CrossRef] [PubMed]

8. Babelova, A.; Moreth, K.; Tsalastra-Greul, W.; Zeng-Brouwers, J.; Eickelberg, O.; Young, M.F.; Bruckner, P.; Pfeilschifter, J.; Schaefer, R.M.; Grone, H.J.; et al. Biglycan, a danger signal that activates the NLRP3 inflammasome via toll-like and P2X receptors. J. Biol. Chem. 2009, 284, 24035-24048. [CrossRef] [PubMed]

9. Moreth, K.; Brodbeck, R.; Babelova, A.; Gretz, N.; Spieker, T.; Zeng-Brouwers, J.; Pfeilschifter, J.; Young, M.F.; Schaefer, R.M.; Schaefer, L. The proteoglycan biglycan regulates expression of the B cell chemoattractant CXCL13 and aggravates murine lupus nephritis. J. Clin. Investig. 2010, 120, 4251-4272. [CrossRef] [PubMed]

10. Kawai, T.; Akira, S. The role of pattern-recognition receptors in innate immunity: Update on toll-like receptors. Nat. Immunol. 2010, 11, 373-384. [CrossRef] [PubMed]

11. Moreth, K.; Frey, H.; Hubo, M.; Zeng-Brouwers, J.; Nastase, M.V.; Hsieh, L.T.; Haceni, R.; Pfeilschifter, J.; Iozzo, R.V.; Schaefer, L. Biglycan-triggered TLR-2- and TLR-4-signaling exacerbates the pathophysiology of ischemic acute kidney injury. Matrix Biol. 2014, 35, 143-151. [CrossRef] [PubMed]

12. Schaefer, L.; Tredup, C.; Gubbiotti, M.A.; Iozzo, R.V. Proteoglycan neofunctions: Regulation of inflammation and autophagy in cancer biology. FEBS J. 2017, 284, 10-26. [CrossRef] [PubMed]

13. Schaefer, L. Extracellular matrix molecules: Endogenous danger signals as new drug targets in kidney diseases. Curr. Opin. Pharmacol. 2010, 10, 185-190. [CrossRef] [PubMed] 
14. Nastase, M.V.; Young, M.F.; Schaefer, L. Biglycan: A multivalent proteoglycan providing structure and signals. J. Histochem. Cytochem. 2012, 60, 963-975. [CrossRef] [PubMed]

15. Hsieh, L.T.; Nastase, M.V.; Zeng-Brouwers, J.; Iozzo, R.V.; Schaefer, L. Soluble biglycan as a biomarker of inflammatory renal diseases. Int. J. Biochem. Cell. Biol. 2014, 54, 223-235. [CrossRef] [PubMed]

16. Schwalm, S.; Pfeilschifter, J.; Huwiler, A. Targeting the Sphingosine Kinase/Sphingosine 1-Phosphate Pathway to Treat Chronic Inflammatory Kidney Diseases. Basic Clin. Pharmacol. Toxicol. 2014, 114, 44-49. [CrossRef] [PubMed]

17. Maceyka, M.; Spiegel, S. Sphingolipid metabolites in inflammatory disease. Nature 2014, 510, $58-67$. [CrossRef] [PubMed]

18. Adams, D.R.; Pyne, S.; Pyne, N.J. Sphingosine kinases: Emerging structure-function insights. Trends Biochem. Sci. 2016, 41, 395-409. [CrossRef] [PubMed]

19. Orr Gandy, K.A.; Obeid, L.M. Targeting the Sphingosine Kinase/Sphingosine 1-Phosphate Pathway in Disease: Review of Sphingosine Kinase Inhibitors. Biochim. Biophys. Acta 2013, 1831, 157-166. [CrossRef] [PubMed]

20. Pitson, S.M.; Moretti, P.A.; Zebol, J.R.; Lynn, H.E.; Xia, P.; Vadas, M.A.; Wattenberg, B.W. Activation of sphingosine kinase 1 by ERK1/2-mediated phosphorylation. EMBO J. 2003, 22, 5491-5500. [CrossRef] [PubMed]

21. Alvarez, S.E.; Harikumar, K.B.; Hait, N.C.; Allegood, J.; Strub, G.M.; Kim, E.Y.; Maceyka, M.; Jiang, H.; Luo, C.; Kordula, T.; et al. Sphingosine-1-phosphate is a missing cofactor for the E3 ubiquitin ligase TRAF2. Nature 2010, 465, 1084-1088. [CrossRef] [PubMed]

22. Harikumar, K.B.; Yester, J.W.; Surace, M.J.; Oyeniran, C.; Price, M.M.; Huang, W.C.; Hait, N.C.; Allegood, J.C.; Yamada, A.; Kong, X.; et al. K63-linked polyubiquitination of transcription factor IRF1 is essential for IL-1-induced production of chemokines CXCL10 and CCL5. Nat. Immunol. 2014, 15, 231-238. [CrossRef] [PubMed]

23. Pchejetski, D.; Nunes, J.; Coughlan, K.; Lall, H.; Pitson, S.M.; Waxman, J.; Sumbayev, V.V. The involvement of sphingosine kinase 1 in LPS-induced Toll-like receptor 4-mediated accumulation of HIF-1 $\alpha$ protein, activation of ASK1 and production of the pro-inflammatory cytokine IL-6. Immunol. Cell Biol. 2011, 89, 268-274. [CrossRef] [PubMed]

24. Lai, W.Q.; Irwan, A.W.; Goh, H.H.; Melendez, A.J.; McInnes, I.B.; Leung, B.P. Distinct roles of sphingosine kinase 1 and 2 in murine collagen-induced arthritis. J. Immunol. 2009, 183, 2097-2103. [CrossRef] [PubMed]

25. Baker, D.A.; Barth, J.; Chang, R.; Obeid, L.M.; Gilkeson, G.S. Genetic Sphingosine Kinase 1 Deficiency Significantly Decreases Synovial Inflammation and Joint Erosions in Murine TNF- $\alpha$-Induced Arthritis. J. Immunol. 2010, 185, 2570-2579. [CrossRef] [PubMed]

26. Geng, T.; Sutter, A.; Harland, M.D.; Law, B.A.; Ross, J.S.; Lewin, D.; Palanisamy, A.; Russo, S.B.; Chavin, K.D.; Cowart, L.A. SphK1 mediates hepatic inflammation in a mouse model of NASH induced by high saturated fat feeding and initiates proinflammatory signaling in hepatocytes. J. Lipid Res. 2015, 56, 2359-2371. [CrossRef] [PubMed]

27. Liang, J.; Nagahashi, M.; Kim, E.Y.; Harikumar, K.B.; Yamada, A.; Huang, W.C.; Hait, N.C.; Allegood, J.C.; Price, M.M.; Avni, D.; et al. Sphingosine-1-Phosphate Links Persistent STAT3 Activation, Chronic Intestinal Inflammation, and Development of Colitis-Associated Cancer. Cancer Cell 2013, 23, 107-120. [CrossRef] [PubMed]

28. Schwalm, S.; Timcheva, T.M.; Filipenko, I.; Ebadi, M.; Hofmann, L.P.; Zangemeister-Wittke, U.; Pfeilschifter, J.; Huwiler, A. Sphingosine kinase 2 deficiency increases proliferation and migration of renal mouse mesangial cells and fibroblasts. Biol. Chem. 2015, 396, 813-825. [CrossRef] [PubMed]

29. Chen, X.L.; Grey, J.Y.; Thomas, S.; Qiu, F.H.; Medford, R.M.; Wasserman, M.A.; Kunsch, C. Sphingosine kinase-1 mediates TNF- $\alpha$-induced MCP-1 gene expression in endothelial cells: Upregulation by oscillatory flow. Am. J. Physiol. Heart Circ. Physiol. 2004, 287, H1452-H1458. [CrossRef] [PubMed]

30. Luheshi, N.M.; Giles, J.A.; Lopez-Castejon, G.; Brough, D. Sphingosine regulates the NLRP3-inflammasome and IL-1 $\beta$ release from macrophages. Eur. J. Immunol. 2012, 42, 716-725. [CrossRef] [PubMed]

31. Schnute, M.E.; McReynolds, M.D.; Kasten, T.; Yates, M.; Jerome, G.; Rains, J.W.; Hall, T.; Chrencik, J.; Kraus, M.; Cronin, C.N.; et al. Modulation of cellular S1P levels with a novel, potent and specific inhibitor of sphingosine kinase-1. Biochem. J. 2012, 444, 79-88. [CrossRef] [PubMed] 
32. Ren, S.; Xin, C.; Pfeilschifter, J.; Huwiler, A. A Novel Mode of Action of the Putative Sphingosine Kinase Inhibitor 2-(p-hydroxyanilino)-4-(p-chlorophenyl) thiazole (SKI II): Induction of Lysosomal Sphingosine Kinase 1 Degradation. Cell. Physiol. Biochem. 2010, 26, 97-104. [CrossRef] [PubMed]

33. Spiegel, S.; Milstien, S. The outs and the ins of sphingosine-1-phosphate in immunity. Nat. Rev. Immunol. 2011, 11, 403-415. [CrossRef] [PubMed]

34. Kilpatrick, L.E.; Lee, J.Y.; Haines, K.M.; Campbell, D.E.; Sullivan, K.E.; Korchak, H.M. A role for PKC- $\delta$ and PI 3-kinase in TNF- $\alpha$-mediated antiapoptotic signaling in the human neutrophil. Am. J. Physiol. Cell. Physiol. 2002, 283, C48-C57. [CrossRef] [PubMed]

35. Mastrandrea, L.D.; Sessanna, S.M.; Laychock, S.G. Sphingosine kinase activity and sphingosine-1 phosphate production in rat pancreatic islets and INS-1 cells: Response to cytokines. Diabetes 2005, 54, 1429-1436. [CrossRef] [PubMed]

36. Olivera, A.; Spiegel, S. Sphingosine-1-phosphate as second messenger in cell proliferation induced by PDGF and FCS mitogens. Nature 1993, 365, 557-560. [CrossRef] [PubMed]

37. Yamanaka, M.; Shegogue, D.; Pei, H.; Bu, S.; Bielawska, A.; Bielawski, J.; Pettus, B.; Hannun, Y.A.; Obeid, L.; Trojanowska, M. Sphingosine kinase 1 (SPHK1) is induced by transforming growth factor-beta and mediates TIMP-1 up-regulation. J. Biol. Chem. 2004, 279, 53994-54001. [CrossRef] [PubMed]

38. Stayrook, K.R.; Mack, J.K.; Cerabona, D.; Edwards, D.F.; Bui, H.H.; Niewolna, M.; Fournier, P.G.; Mohammad, K.S.; Waning, D.L.; Guise, T.A. TGF $\beta$-Mediated induction of SphK1 as a potential determinant in human MDA-MB-231 breast cancer cell bone metastasis. Bonekey Rep. 2015, 4, 719. [CrossRef] [PubMed]

39. Rius, R.A.; Edsall, L.C.; Spiegel, S. Activation of sphingosine kinase in pheochromocytoma PC12 neuronal cells in response to trophic factors. FEBS Lett. 1997, 417, 173-176. [CrossRef]

40. Schonherr, E.; Jarvelainen, H.T.; Kinsella, M.G.; Sandell, L.J.; Wight, T.N. Platelet-derived growth factor and transforming growth factor-beta 1 differentially affect the synthesis of biglycan and decorin by monkey arterial smooth muscle cells. Arterioscler. Thromb. 1993, 13, 1026-1036. [CrossRef] [PubMed]

41. Schaefer, L.; Beck, K.F.; Raslik, I.; Walpen, S.; Mihalik, D.; Micegova, M.; Macakova, K.; Schonherr, E.; Seidler, D.G.; Varga, G.; et al. Biglycan, a nitric oxide-regulated gene, affects adhesion, growth, and survival of mesangial cells. J. Biol. Chem. 2003, 278, 26227-26237. [CrossRef] [PubMed]

42. Schwiebs, A.; Friesen, O.; Katzy, E.; Ferreiros, N.; Pfeilschifter, J.M.; Radeke, H.H. Activation-induced cell death of dendritic cells is dependent on sphingosine kinase 1. Front. Pharmacol. 2016, 7, 94. [CrossRef] [PubMed]

43. Prakash, H.; Luth, A.; Grinkina, N.; Holzer, D.; Wadgaonkar, R.; Gonzalez, A.P.; Anes, E.; Kleuser, B. Sphingosine Kinase-1 (SphK-1) Regulates Mycobacterium smegmatis Infection in Macrophages. PLoS ONE 2010, 5, e10657. [CrossRef] [PubMed]

44. Fernandez-Pisonero, I.; Duenas, A.I.; Barreiro, O.; Montero, O.; Sanchez-Madrid, F.; Garcia-Rodriguez, C. Lipopolysaccharide and sphingosine-1-phosphate cooperate to induce inflammatory molecules and leukocyte adhesion in endothelial cells. J. Immunol. 2012, 189, 5402-5410. [CrossRef] [PubMed]

45. Aoki, M.; Aoki, H.; Ramanathan, R.; Hait, N.C.; Takabe, K. Sphingosine-1-phosphate signaling in immune cells and inflammation: Roles and therapeutic potential. Mediat. Inflamm. 2016, 2016, 8606878. [CrossRef] [PubMed]

46. Xiong, Y.; Lee, H.J.; Mariko, B.; Lu, Y.C.; Dannenberg, A.J.; Haka, A.S.; Maxfield, F.R.; Camerer, E.; Proia, R.L.; Hla, T. Sphingosine kinases are not required for inflammatory responses in macrophages. J. Biol. Chem. 2013, 288, 32563-32573. [CrossRef] [PubMed]

47. Jung, I.D.; Lee, J.S.; Kim, Y.J.; Jeong, Y.I.; Lee, C.M.; Baumruker, T.; Billlich, A.; Banno, Y.; Lee, M.G.; Ahn, S.C.; et al. Sphingosine kinase inhibitor suppresses a Th1 polarization via the inhibition of immunostimulatory activity in murine bone marrow-derived dendritic cells. Int. Immunol. 2007, 19, 411-426. [CrossRef] [PubMed]

48. Elass-Rochard, E.; Rombouts, Y.; Coddeville, B.; Maes, E.; Blervaque, R.; Hot, D.; Kremer, L.; Guerardel, Y. Structural determination and Toll-like Receptor 2-dependent Proinflammatory Activity of Dimycolyl-diarabino-glycerol from Mycobacterium marinum. J. Biol. Chem. 2012, 287, 34432-34444. [CrossRef] [PubMed]

49. Xia, P.; Wang, L.; Moretti, P.A.; Albanese, N.; Chai, F.; Pitson, S.M.; d'Andrea, R.J.; Gamble, J.R.; Vadas, M.A. Sphingosine Kinase Interacts with TRAF2 and Dissects Tumor Necrosis Factor- $\alpha$ Signaling. J. Biol. Chem. 2002, 277, 7996-8003. [CrossRef] [PubMed] 
50. He, X.; Pu, G.; Tang, R.; Zhang, D.; Pan, W. Activation of Nuclear Factor Kappa B in the Hepatic Stellate Cells of Mice with Schistosomiasis Japonica. PLoS ONE 2014, 9, e104323. [CrossRef] [PubMed]

51. Wu, W.; Mosteller, R.D.; Broek, D. Sphingosine kinase protects lipopolysaccharide-activated macrophages from apoptosis. Mol. Cell. Biol. 2004, 24, 7359-7369. [CrossRef] [PubMed]

52. Cummings, R.; Zhao, Y.; Jacoby, D.; Spannhake, E.W.; Ohba, M.; Garcia, J.G.; Watkins, T.; He, D.; Saatian, B.; Natarajan, V. Protein Kinase C $\delta$ Mediates Lysophosphatidic Acid-induced NF-кB Activation and Interleukin-8 Secretion in Human Bronchial Epithelial Cells. J. Biol. Chem. 2004, 279, 41085-41094. [CrossRef] [PubMed]

53. Adada, M.M.; Orr-Gandy, K.A.; Snider, A.J.; Canals, D.; Hannun, Y.A.; Obeid, L.M.; Clarke, C.J. Sphingosine Kinase 1 Regulates Tumor Necrosis Factor-mediated RANTES Induction through p38 Mitogen-activated Protein Kinase but Independently of Nuclear Factor кB Activation. J. Biol. Chem. 2013, 288, 27667-27679. [CrossRef] [PubMed]

54. Mendez-Samperio, P.; Perez, A.; Trejo, A. Sphingosine kinase, phosphatidylinositol 3-kinase, Akt, NF- kB, and p300 are required for CCL5 production in Mycobacterium bovis Bacillus Calmette-Guérin (BCG)-infected epithelial cells. Cell. Immunol. 2007, 249, 94-100. [CrossRef] [PubMed]

55. Mendez-Samperio, P.; Trejo, A.; Perez, A. Mycobacterium bovis Bacillus Calmette-Guérin Induces CCL5 Secretion via the Toll-like receptor 2-NF-KB and -Jun N-Terminal Kinase Signaling Pathways. Clin. Vaccine Immunol. 2008, 15, 277-283. [CrossRef] [PubMed]

56. Dinarello, C.A. Anti-inflammatory agents: Present and future. Cell 2010, 140, 935-950. [CrossRef] [PubMed]

57. Sedger, L.M.; McDermott, M.F. TNF and TNF-receptors: From mediators of cell death and inflammation to therapeutic giants: Past, present and future. Cytokine Growth Factor Rev. 2014, 25, 453-472. [CrossRef] [PubMed]

58. Sweeney, S.E.; Firestein, G.S. Mitogen activated protein kinase inhibitors: Where are we now and where are we going? Ann. Rheum. Dis. 2006, 65, 83-88. [CrossRef] [PubMed]

59. Wadgaonkar, R.; Patel, V.; Grinkina, N.; Romano, C.; Liu, J.; Zhao, Y.; Sammani, S.; Garcia, J.G.; Natarajan, V. Differential regulation of sphingosine kinases 1 and 2 in lung injury. Am. J. Physiol. Lung Cell. Mol. Physiol. 2009, 296, 603-613. [CrossRef] [PubMed]

60. Zhao, Y.; Kalari, S.K.; Usatyuk, P.V.; Gorshkova, I.; He, D.; Watkins, T.; Brindley, D.N.; Sun, C.; Bittman, R.; Garcia, J.G.; et al. Intracellular generation of sphingosine 1-phosphate in human lung endothelial cells: Role of lipid phosphate phosphatase-1 and sphingosine kinase 1. J. Biol. Chem. 2007, 282, 14165-14177. [CrossRef] [PubMed]

61. Oskeritzian, C.A.; Alvarez, S.E.; Hait, N.C.; Price, M.M.; Milstien, S.; Spiegel, S. Distinct roles of sphingosine kinases 1 and 2 in human mast-cell functions. Blood 2008, 111, 4193-4200. [CrossRef] [PubMed]

62. Thompson, J.; Wilson, P.; Brandewie, K.; Taneja, D.; Schaefer, L.; Mitchell, B.; Tannock, L.R. Renal accumulation of biglycan and lipid retention accelerates diabetic nephropathy. Am. J. Pathol. 2011, 179, 1179-1187. [CrossRef] [PubMed]

63. Gulyas, M.; Dobra, K.; Hjerpe, A. Expression of genes coding for proteoglycans and Wilms' tumour susceptibility gene 1 (WT1) by variously differentiated benign human mesothelial cells. Differentiation 1999, 65, 89-96. [CrossRef] [PubMed]

64. Nastase, M.V.; Iozzo, R.V.; Schaefer, L. Key roles for the small leucine-rich proteoglycans in renal and pulmonary pathophysiology. Biochem. Biophys. Acta 2014, 1840, 2460-2470. [CrossRef]

65. Yaghobian, D.; Don, A.S.; Yaghobian, S.; Chen, X.; Pollock, C.A.; Saad, S. Increased sphingosine 1-phosphate mediates inflammation and fibrosis in tubular injury in diabetic nephropathy. Clin. Exp. Pharmacol. Physiol. 2016, 43, 56-66. [CrossRef] [PubMed]

66. Ren, S.; Babelova, A.; Moreth, K.; Xin, C.; Eberhardt, W.; Doller, A.; Pavenstadt, H.; Schaefer, L.; Pfeilschifter, J.; Huwiler, A. Transforming growth factor- $\beta 2$ upregulates sphingosine kinase-1 activity, which in turn attenuates the fibrotic response to TGF- $\beta 2$ by impeding CTGF expression. Kidney Int. 2009, 76, 857-867. [CrossRef] [PubMed]

67. Koch, A.; Pfeilschifter, J.; Huwiler, A. Sphingosine 1-phosphate in renal diseases. Cell. Physiol. Biochem. 2013, 31, 745-760. [CrossRef] [PubMed]

68. Schwalm, S.; Pfeilschifter, J.; Huwiler, A. Sphingosine-1-phosphate: A janus-faced mediator of fibrotic diseases. Biochim. Biophys. Acta 2013, 1831, 239-250. [CrossRef] [PubMed] 
69. Bartels, K.; Grenz, A.; Eltzschig, H.K. Sphingosine-1-phosphate receptor signaling during acute kidney injury: The tissue is the issue. Kidney Int. 2014, 85, 733-735. [CrossRef] [PubMed]

70. Jo, S.K.; Bajwa, A.; Ye, H.; Vergis, A.L.; Awad, A.S.; Kharel, Y.; Lynch, K.R.; Okusa, M.D. Divergent roles of sphingosine kinases in kidney ischemia-reperfusion injury. Kidney Int. 2009, 75, 167-175. [CrossRef] [PubMed]

71. Park, S.W.; Kim, M.; Kim, M.; d'Agati, V.D.; Lee, H.T. Sphingosine kinase 1 protects against renal ischemia-reperfusion injury in mice by sphingosine-1-phosphate1 receptor activation. Kidney Int. 2011, 80, 1315-1327. [CrossRef] [PubMed]

(C) 2017 by the authors. Licensee MDPI, Basel, Switzerland. This article is an open access article distributed under the terms and conditions of the Creative Commons Attribution (CC BY) license (http:/ / creativecommons.org/licenses/by/4.0/). 